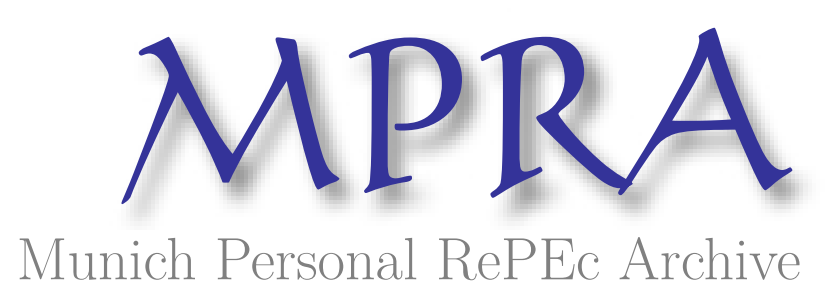

\title{
The Equation of Exchange: A Derivation
}

Hunte, C.K

Howard University

26 September 2011

Online at https://mpra.ub.uni-muenchen.de/43531/

MPRA Paper No. 43531, posted 07 Jan 2013 03:59 UTC 


\title{
The Equation of Exchange: A Derivation
}

by

\author{
C. Kenrick Hunte*
}

\begin{abstract}
This paper provides a theoretically plausible model to explain the equation of exchange, deriving it from an agent's utility maximization problem and the profit maximizing behavior of a competitive firm. It shows that the marginal propensity to consume is constant, while the average propensity to consume is decreasing as income increases. Supporting the notion that consumption growth is positively related to income growth, it confirms that the marginal propensity to consume has a theoretical basis for modifying velocity, money demand and consumption, given that money demand is inversely related to the interest rate and positively related to income.
\end{abstract}

Keywords: Equation of exchange; money demand; income velocity; marginal propensity to consume.

JEL (D01, E21, E41, E43)

*Associate Professor, Department of Economics, Howard University; email: CHunte@Howard.edu;. The author is grateful for helpful comments made by an anonymous referee; all errors are the author's. 


\section{The Equation of Exchange: A Derivation}

\section{Introduction}

2011 marks just over one hundred years since Irving Fisher (1911) published the now famous, "Equation of Exchange." During this span of time, many economists have built and tested models and suggested policy implications based on the use of this equation, including, among a long list of economists, and to name only a few, are Keynes (1936); Friedman (1956); Friedman and Schwartz (1963); Klein (1973); Bordo and Jonung (1981); and Siklos (1993). In addition, standard macroeconomic textbooks and textbooks on money, banking and financial markets, typically include a few paragraphs on the equation of exchange, thereby signaling its relative importance in the study of economics.

Obviously, writing a paper on a topic that is part of the long established core of macroeconomic investigation seems to be a redundant exercise, except for the fact that the theoretical foundation for the equation of exchange was not well defined these past one hundred years. The equation of exchange is typically introduced as an accounting identity that is devoid of the underlying behavioral relationships that capture the utility maximizing behavior of the representative agent and the profit maximizing behavior of the competitive firm. Hence, the main purpose of this paper is deriving the equation of exchange using appropriate optimizing techniques.

In discussing the equation of exchange and the subject of velocity, Fisher (1911) stated that transaction velocity "is the quotient obtained by dividing the total money payments for goods in the course of a year by the average amount of money in circulation...." Specifically, velocity (V) is defined by Fisher's identity as $\mathrm{V}=(\mathrm{PT}) / \mathrm{M}$, where $\mathrm{P}$ is the price of a typical transaction, and $\mathrm{T}$ is the number of times goods and services are exchanged for money 
(M) by households and business firms. In subsequent work by the Cambridge School, T was replaced by total output (Y), with $\mathrm{P}$ representing the price of one unit of output in the economy and with the income velocity being specified as $\mathrm{V}=(\mathrm{PY}) / \mathrm{M}$. In addition, by multiplying both sides by $\mathrm{M}$, we observe the equation of exchange MV $=\mathrm{PY}$. This identity conveys the notion that the quantity of money (M) times the velocity of money (V) is equal to the value of nominal spending in the economy (PY). According to Fisher (1911), velocity is assumed constant, when there is no financial innovation and interest rates are assumed to be fixed.

While the equation of exchange is important in explaining how the economy is structured, its limitation is that it does not appear to be derived from a microeconomic framework for both the typical agent and the competitive firm. Moreover, as an accounting identity, it precludes the use of any behavioral equations and it is a summary measure of economic activity in the economy. Besides, since the income velocity of money is defined as the speed with which money changes hands, then it is likely that the behavior of the firm and agent must be more explicitly expressed in the equation of exchange as consumption and firm behavior would change when the price level, income, money or the interest rate change in the economy. Furthermore, since money is used to acquire goods and services that in turn impacts consumption, it is posited that the income velocity of money is positively related to the marginal propensity to consume, given that money and consumption are arguments in the utility function of the representative agent.

Of course, it could be argued that the microeconomic foundation of the equation of exchange may not have been an important concern when Fisher first proposed it in 1911; instead, the research emphasis at that time may have been aimed at understanding the linkages between aggregate demand 
and money markets. This is one approach used to study aggregate demand by Blanchard and Kiyotaki (1987) and Rotemberg (1987), with Romer (2001) adding that they should have included velocity to identify aggregate demand disturbances that are separate from money supply shifts.

The equation of exchange has also been applied by many researchers in the classical quantity theory of inflation under the assumption that the price level is proportional to the money stock, when both $\mathrm{V}$ and $\mathrm{Y}$ are fixed (Friedman, M and A. Schwartz, 1963; Dornbusch, Fisher and Startz, 2008). Yet it is the agent's decision on consumption, money balances, and the supply of labor to the firm together with the firm's demand for labor and its profit maximizing output that simultaneously have an impact on income velocity. Consequently, if a more complete understanding of the relationship is to be obtained, it is argued that the equation of exchange should incorporate the behavioral relationships and interactions of households and competitive firms.

More specifically, since it is posited that the equation of exchange is rooted in the utility maximizing behavior of the agent and profit maximizing behavior of the competitive firm, a theoretically plausible model that captures these relationships is important for deriving the equation of change. Some of the findings in this paper are that not only is the equation of exchange derived from a utility maximizing model and that velocity is constant when interest rates are fixed, but it is demonstrated that net wealth is positively related to the average propensity to consume, an outcome that supports the positive relationship between wealth and consumption. Equally important is the fact that the marginal propensity to consume modifies income velocity, money demand and consumption, even as the interest rate is inversely related to money demand. The three remaining sections of this paper are as follows: the next section presents a brief overview of the 
literature on money being included in utility functions; followed by a presentation of the model proposed in the paper, with concluding remarks in the last section.

\section{Money in a Utility Function}

A utility function with money included has its genesis in the work by Sidrauski (1967). He contends that the representative agent's utility is influenced by real consumption and real money balances, adding that the utility curve is strictly concave, twice differentiable and that both real consumption and real money balances are not inferior either as a good in the case of real consumption or as a service in the case of real money balances. Researchers who have used this approach include Blanchard and Kiyotaki (1987); Porterba and Rotemberg (1986); Husted and Rush (1984); Koenig (1990), as have many others.

Recognizing that the opportunity cost of holding money balances is not zero as it represents a loss of income for the typical agent, it is generally accepted that holding money balances, a non-interest bearing asset, is costly, resulting in the loss of interest income (Baumol 1952; Tobin 1956). Yet the typical agent may still have a strong preference for holding money, because the agent may be motivated by the notion that real money balances provide liquidity services as it reduces the agent's transaction costs, while increasing the agent's utility. The cash in advance model captures this idea, where it is assumed that all goods and services must be fully paid for with money at the time of purchase (Lucas, 1980; Clower 1967).

Holding real money balances may also be associated with saving time spent on shopping. In this regard, McCallum and Goodfriend (1989) introduce the 'shopping-time' model in an effort to motivate the demand for money, where money is assumed to be an intermediate good (Ljungqvist and 
Sargent, 2004; Wickens 2008). It has also been posited that by including money in the utility function, this allows the precautionary and store of value motives to be examined (Holman 1998).

In the literature on money in utility functions, researchers frequently use the Cobb-Douglas function ( $\mathrm{CDF})$, the nested $\mathrm{CDF}$, constant-elasticity-ofsubstitution (CES), and the nested CES when studying the issues associated with money and consumption (Poterba and Rotemberg 1987; Finn, Hoffman and Schlagenhauf 1990; Holman, 1998). An important difference, however, between the $\mathrm{CDF}$ and the other functional forms is that whereas, for

example, the CDF imposes unitary elasticity of substitution between real balances and consumption and it displays constant risk aversion, the other functional forms provide flexibility in determining the estimated coefficients without their being an a-priori imposition, as is the case with the CDF. Holman (1998) conducts an econometric study of these functional forms in which money is included in the utility function based on a dynamic model and finds that real money balances improves the agent's utility, adding that money in utility functions cannot be rejected for most of the cases examined. For ease of exposition, the CDF is used in this paper, instead of a more general function, such as the CES, since the focus of the paper is to present a theoretical framework for deriving the income velocity from an optimizing agent and a competitive firm. It should be pointed out, however, that the CDF is a special case of the CES when the substitution parameter in the CES is zero (Chiang 1974).

\section{Model}

The equation of exchange is derived from considering an agent who seeks to maximize a money-in-utility function subject to an income constraint. It is assumed that the utility function (U) is increasing in real consumption (C) 
and real money balances $(\mathrm{M} / \mathrm{P})$, and it is twice differentiable, with $\mathrm{P}$ as the price level and $\mathrm{M}$ as nominal money. The real consumption constraint is equal to the sum of income from real wages $(w / p)$ times the number of labor units (Ls) supplied by the household; and real interest income from net wealth $(\mathrm{NW})^{1}$ times the real interest rate $(\mathrm{r} / \mathrm{p})$, minus the opportunity cost of holding money-- $\mathrm{M}$ times the real interest rate $(\mathrm{r} / \mathrm{p})$ :

$$
C=\left(\frac{w}{p}\right) L_{s}+\left(\frac{r}{p}\right) N W-\left(\frac{r}{p}\right) M
$$

The profit-maximizing firm demands labor based on a production function:

$$
Y=\bar{K} L^{\beta} \quad 0<\beta<1
$$

where $\mathrm{Y}$ is real output; $\mathrm{K}$ is capital (fixed); and $\mathrm{L}$ is labor. Assuming perfect competition, where the marginal product of labor $\left(\mathrm{MPL}=\frac{\beta Y}{L}\right)$ is equal to the real wage $\left(\frac{\beta Y}{L}=\mathrm{w} / \mathrm{p}\right)$, this result allows equation 1 to be rewritten as:

$$
C=\beta Y+\left(\frac{r}{p}\right) N W-\left(\frac{r}{p}\right) M
$$

The agent's utility maximizing model is therefore specified as:

$$
\begin{aligned}
& \underset{C, .(M \backslash P)}{\operatorname{Max}}: \alpha \ln C+\ln \left(\frac{M}{P}\right) \quad \alpha>0 \\
& \text { s.t }: C=\beta Y+\left(\frac{r}{P}\right) N W-\left(\frac{r}{P}\right) M
\end{aligned}
$$

with the constrained optimization problem specified as:

$$
L: \quad \alpha \ln (C)+\operatorname{Ln}\left(\frac{M}{P}\right)+\lambda\left(\beta Y+\left(\frac{r}{p}\right) N W-r\left(\frac{M}{P}\right)-C\right)
$$


The necessary first order conditions for optimality are:

$$
\begin{gathered}
\frac{\partial L}{\partial C}: \frac{\alpha}{C}-\lambda=0 \\
\frac{\partial L}{\partial(M / P)}: \frac{1}{(M / P)}-r \lambda=0 \\
\frac{\partial L}{\partial \lambda}: \beta Y+\frac{r}{P}(N W)-r\left(\frac{M}{P}\right)-C=0
\end{gathered}
$$

Substituting equation 6 into equation 7 yields:

$$
C=\alpha r\left(\frac{M}{P}\right)
$$

Substitute equation 9 into equation 8 to obtain a derived money demand equation:

$$
\left(\frac{M}{P}\right)=\frac{\beta Y}{(1+\alpha) r}+\frac{N W}{(1+\alpha) P}
$$

where real money balance is proportional to income and net-wealth and is inversely related to the interest rate. Substituting equation 10 into equation 9 yields a derived consumption function:

$$
C=\left(\frac{\alpha \beta Y}{(1+\alpha)}\right)+\left(\frac{\alpha \cdot r N W}{(1+\alpha) P}\right)
$$

This result confirms that consumption is proportional to income and net-wealth; that the average propensity to consume (APC) is decreasing in income (equation 12), but increasing in net-wealth, with the marginal propensity to consume (MPC) being constant (equation 13):

$$
A P C=\left(\frac{C}{Y}\right)=\frac{\alpha \beta}{(1+\alpha)}+\frac{\alpha}{(1+\alpha)}\left(\frac{r}{P Y}\right) N W
$$




$$
\overline{M P C}=\frac{\Delta C}{\Delta Y}=\frac{\alpha \beta}{(1+\alpha)}
$$

Substituting MPC in equation 13 into the APC in equation 12 yields:

$$
\begin{aligned}
& A P C=\overline{M P C}+\frac{\overline{M P C}}{\beta}\left(\frac{r}{P Y}\right) N W \\
& A P C=\overline{M P C}\left[1+\frac{1}{\beta}\left(\frac{r}{P Y}\right) N W\right]
\end{aligned}
$$

This result implies that APC increases when the real income from net wealth increases and decreases when real income increases, but both of these changes in APC are conditioned by the magnitude of the MPC. Dividing equation 14 by MPC implies that the growth in consumption is positively related to income growth:

$$
\begin{aligned}
& \left(\frac{A P C}{\overline{M P C}}\right)=\left[1+\frac{1}{\beta}\left(\frac{r}{P Y}\right) N W\right] \\
& \dot{Y}=\dot{C}\left[1+\frac{1}{\beta}\left(\frac{r}{P Y}\right) N W\right]
\end{aligned}
$$

where $\dot{Y}$ and $\dot{C}$ are growth rates for income and consumption, respectively. This result implies that increases in net wealth increases economic growth, as does the growth in consumption. Finally, because saving is equal to the difference between income $(\mathrm{Y})$ and consumption $(\mathrm{C})$, it observed that the growth in saving $(\mathrm{S})$ is specified as:

$$
\dot{S}=\dot{C}\left[\frac{1}{\beta}\left(\frac{r}{P Y}\right) N W\right]
$$

indicating that increases in net-wealth increases the growth in the saving rate. Substituting equation 13 into equation 10 yields a money demand function that is conditioned by the magnitude of the MPC: 


$$
\frac{M}{P}=\frac{\overline{M P C}}{\alpha}\left(\frac{Y}{r}+\frac{1}{\beta} \frac{N W}{P}\right)
$$

Similarly, substituting equation 13 into equation 11 yields a consumption function that is also conditioned by the magnitude of MPC:

$$
C=\overline{M P C}\left(Y+\frac{r}{\beta} \frac{N W}{P}\right)
$$

Solving equation 10 for $\mathrm{Y}$ and multiplying both sides by $\mathrm{P} / \mathrm{M}$, yields the derived income velocity of money (V):

$$
\begin{aligned}
& V=\left(\frac{P Y}{M}\right)=\left[(1+\alpha)-\frac{N W}{M}\right]\left(\frac{r}{\beta}\right) \\
& V=\left[\frac{\overline{M P C}}{\beta}-\frac{N W}{M}\right]\left(\frac{r}{\beta}\right)
\end{aligned}
$$

Alternatively, equation 19 can be written as:

$$
M V=P Y=M\left[\frac{\overline{M P C}}{\beta}-\frac{N W}{M}\right]\left(\frac{r}{\beta}\right)
$$

The result in equation 20 confirms that the equation of exchange is a special accounting identity that is derived from the optimizing behavior of the agent and the competitive firm. Assuming that the ratio of net wealth (NW) to money $(\mathrm{M})$ in equation 20 is a constant theta $(\theta)$ :

$$
\frac{N W}{M}=\theta \quad \theta \geq 0
$$

and substituting equation 21 into equation 20 shows that velocity is positively related to the interest rate:

$$
V=\left[\frac{\overline{M P C}}{\beta^{2}}-\frac{\theta}{\beta}\right] r>0 \quad \text { if. } \overline{M P C}>\beta \theta
$$

More importantly, equation 22 confirms that the marginal propensity to 
consume (MPC) is positively related to the income velocity of money and it confirms the Fisher idea of the existence of a constant velocity of income when the interest rate is fixed. Furthermore, it also confirms that the income velocity of money increases with increases in the interest rate.

\section{Concluding Remarks}

This paper provides a theoretically plausible model to explain the equation of exchange that is derived from the solution to an agent's utility maximization problem and the profit maximizing behavior of a competitive firm. The model proposed in the paper not only confirms this proposition, but it also indicates that the marginal propensity to consume has a theoretical basis for modifying velocity, money demand and consumption. The paper also supports the notion advanced by Fisher that the income velocity is constant when the interest is fixed. In addition, it shows that the marginal propensity to consume is constant, while the average propensity to consume is decreasing as income increases, an outcome that is consistent with the consumption function advanced by Keynes; and finally, it provides support for the notion that consumption growth is positively related to income growth.

\section{Notes}

1. Net Wealth $=$ Total Assets - Total Liabilities. Total assets include Bonds, among other assets. 


\section{References}

Baumol, William. 1952. "The Transaction Demand for Cash: An Inventory Theoretic Approach," Quarterly Journal of Economics 66, November, 545-556.

Blanchard, Oliver, J., Nobuhiro Kiyotaki. 1987. "Monopolistic Competition and the Effect of Aggregate Demand." American Economic Review 77, September, 647-666.

Bordo, M and Jonung, L. 1981. "The Long-run Behavior of the Income Velocity of Money in Five Advanced Countries, 1870-1975: an Institutional Approach" Economic Inquiry: 537-545.

Chiang, Alpha. 1974. "Fundamental Methods of Mathematical Economics," USA: Mc Graw-Hill.

Clower, Robert W. 1967. "A reconsideration of the Microfoundations of Monetary Theory," Western Economic Journal: 6, 1-8.

Dornbusch, Rudiger, Stanley Fischer and Richard Startz . 2008.

"Macroeconomics," (Tenth Edition), New York: McGraw-Hill, Irwin.

Finn, Mary G., Dennis L Hoffman, and Don E. Schlagenhauf. 1990, "Intertemporal Asset-Pricing Relationships in Barter and Monetary Economies." Journal of Monetary Economics 25, June, 431-51.

Fisher, Irving. 1911. "The Purchasing Power of Money," New York: Macmillan

Friedman, Milton . 1956. "The Quantity Theory of Money: A Restatement," in Milton Friedman, ed., Studies in the Quantity Theory of Money, Chicago: University of Chicago Press.

Friedman, M and A. Schwartz. 1963. A Monetary History of the United States: 1867-1960. Princeton, N.J: Princeton University Press.

Holman, Jill A. 1998. "GMM Estimation of a Money-in-the-UtilityFunction Model: The Implications of Functional Forms." Journal of Money Credit and Banking, Vol. 30 No. 4, 679-698. 
Husted, Steven and Mark Rush. 1984. "On Measuring the Nearness of Near Money: Revisited," Journal of Monetary Economics 14, 171-182.

Keynes, John. M. 1936. "The General Theory of Employment, Interest and Money," London: Macmillan.

Klein, B. 1973. "Income Velocity, Interest Rates and Money Supply Multiplier: A Reinterpretation of the long-term evidence." Journal of Money, Credit and Banking, 5(2), pp. 656-668.

Koenig, Evan F. 1990. "Real Money Balances and the timing of Consumption.” The Quarterly Journal of Economics, 105, May, 399-425.

Ljugquist, Lars and Thomas J. Sargent. 2004. Recursive Macroeconomic Theory. Cambridge, MA: MIT Press.

Lucas, R.E. 1980. “Equilibrium in a pure currency economy”. In Models of Monetary Economies (ed. J.H Karaken and N.Wallace), 31-45. Federal Reserve Bank of Minneapolis.

McCallum, Bennett T., and Marvin S. Goodfriend. 1989. "Demand for Money: Theoretical Studies." in The New Palgrave: Money, edited by J. Eatwell, M. Milgrate, and P. Newman. New York: W.W. Norton, 1989.

Poterba, James M, and Julio J. Rotemberg . 1986, "Money in the Utility Function: An Empirical Implementation,” NBER Working Paper, No. 1796.

Romer, David. 2001. "Advanced Macroeconomics," (Second Edition), New York: McGraw-Hill.

Rotemberg, Julio J. 1987. "The New Keynesian Microfoundations." NBER Macroeconomics Annual 2: 69-104.

Sidrauski, Miguel. 1967. "Rational Choice and patterns of Growth in a Monetary Economy," The American Economic Review, Vol. 57, No. 2, Papers and Proceedings of the Seventy-ninth Annual Meeting of the American Economic Association, May, 534-544.

Siklos, Pierre, L. 1993." Income Velocity and Institutional Change: Some 
New Time Series Evidence, 1870-1986". Journal of Money Credit and Banking, 25(3), 377-92.

Tobin, James. 1956. "The Interest Elasticity of the Transaction Demand for Cash", Review of Economics and Statistics, August, pp 241-247.

Wickens, Michael. 2008. "Macroeconomic Theory," Princeton New Jersey: University Press. 